\title{
Preparing of Cornstarch (Zea mays) Bioplastic Using ZnO Metal
}

\author{
Nurwani Hayati ${ }^{*}$, and Lazulva \\ Jurusan Pendidikan Kimia, Universitas Islam Negeri Sultan Syarif Kasim Riau Pekanbaru \\ JI. HR. Soebrantas No. 155 KM. 18, Simpang Baru, Panam, Pekanbaru 28293 Po.Box. \\ *Email : nurwanihayati@ymail.com
}

\begin{abstract}
.
The manufacture of the bioplastic was done through the mixing process using an aquades solvent with a ratio massa 10 gram and 7 gram cornstarch, $150 \mathrm{~mL}$ aquades, $2 \mathrm{Ml}$ glycerol and 0,5 gram ZnO. This study aim to find out physical characteristies (water vapour transmission rate, water content, thickness, biodegradation) and mechanical charateristics (tensile strength, elongasi, modulus young) are made of cornstrach (Zea mays) using $\mathrm{ZnO}$ metal. From the test results tensile strength was 2.744-4.018 Mpa, percentage of elongation was 28.46$32.383 \%$, modulus young's was 8.9031026535-14.08617709Mpa, thickness was 0.16-0.29mm, water vapor transmission rate was $0.4329-1.52525 \mathrm{~g} / \mathrm{m} 2.24$ hours, water content was $13.5-14.5 \%$, and biodegradation was 3.7798-7.0346\% and 455-809 days.
\end{abstract}

Keywords: Bioplastic, Zea mays, ZnO

\section{Pendahuluan}

Berbagai upaya dan inovasi untuk mengurangi dampak sampah plastik telah dilakukan. Salah satu diantaranya dewasa ini telah dikembangkan plastik ramah lingkungan yang berasal dari bahan alam seperti pati, selulosa, kolagen, kasein, protein atau lipid yang terdapat dalam hewan. Plastik tersebut mudah diuraikan oleh mikroba pengurai, yang disebut dengan bioplastik. Salah satu bahan utama dalam pembuatan bioplastik adalah pati. Jenis tanaman yang banyak memiliki kandungan pati adalah Jagung. Jagung (Zea mays) merupakan salah satu tanaman pangan dunia yang terpenting, selain gandum dan padi. Komponen utama jagung adalah pati, yaitu sekitar $70 \%$ dari bobot biji. Komponen karbohidrat lain adalah gula sederhana, yaitu glukosa, sukrosa, dan fruktosa hanya 1\%-3\% dari bobot biji jagung. Tepung jagung dapat diperoleh dengan cara mengekstrak biji jagung. Komposisi kimia tepung jagung adalah: karbohidrat $(74,5 \%)$, protein $(9 \%)$, serat $(1 \%)$, abu $(1,1 \%)$ dan lemak $(3,4 \%){ }^{1}$ Oleh karena itu sehingga peneliti tertarik untuk memanfaatkan tepung jagung sebagai bahan utama dalam pembuatan bioplastik.

Berdasarkan penelitian sebelumnya dijelaskan bahwa tepung jagung (Zea mays) dan kitosan dapat dijadikan sebagai bahan utama dalam pembuatan bioplastik. Dan ubi jalar dengan menggunakan penguat logam $\mathrm{ZnO}$ dapat dijadikan sebagai bioplastik dan menjadikan $\mathrm{ZnO}$ sebagai bahan penguat tambahan pada bioplastik. Plasticizer merupakan salah satu bahan tambahan dalam pembuatan bioplastik. ${ }^{2}$ Tujuan penambahan plasticizer untuk menambah sifat elastisitas dan fleksibilitas pada bioplastik. Namun, pati tersebut mempunyai kelemahan, yaitu sifat mekanik yang kurang baik. Partikel penguat telah terbukti dapat memperbaiki kelemahan pati dari penelitian sebelumnya. Adanya bahan penguat dalam 
biopolimer akan memberikan pengaruh pada sifatsifat komposit yang terbentuk. ${ }^{3}$ Penguat akan meningkatkan kekuatan pada pati. ZnO merupakan bahan yang bersifat piezoelektrik, bio-safe dan biocompatible dengan pati. ${ }^{4}$ Penelitian ini diharapkan dapat menjadikan $\mathrm{ZnO}$ sebagai penguat pada matriks pati.

\section{Metodologi Penelitian}

2.1. Bahan kimia, peralatan dan instrumentasi

Bahan yang digunakan dalam penelitian ini adalah tepung jagung kemasan dengan merk Maizena diperoleh di toko Indomaret Pekanbaru, Zinc Oxide ( $\mathrm{ZnO})$, gliserol, aquades dan silica gel. Alat yang digunakan dalam penelitian ini adalah sebagai berikut: neraca analitik, gelas beaker 500 $\mathrm{mL}$, magnetic stirer, pipet tetes, spatula, kaca arloji, gelas ukur, hot plate, penjepit, cawan petri, termometer, plat kaca (cetakan), desikator, Gotech Al-7000M, dan Alat Uji Mitutoyo.

2.2. Prosedur penelitian

\subsubsection{Pembuatan Bioplastik}

Tepung jagung ditimbang menggunakan neraca analitik sebanyak 10 gram, 0,5 gram $\mathrm{ZnO}$. Lalu di ambil sebanyak $2 \mathrm{~mL}$ gliserol dari gelas ukur dan $150 \mathrm{~mL}$ aquades. Pati jagung, $\mathrm{ZnO}$, gliserol dan aquades di masukan kedalam gelas beaker berukuran $500 \mathrm{~mL}$ aduk sampai semua bahan tercampur, kemudian dimasukan ke dalam water bath lalu kocok sampai mengental dengan suhu $80^{\circ} \mathrm{C}$. Setelah larutan mengental lalu di tuangkan kedalam plat kaca (cetakan) dan kering angin selama 3 hari. Lakukan kembali untuk tepung jagung 7 gram. Setelah bioplastik mengering kemudian dilepaskan dari cetakan. Bioplastik siap untuk dilakukan pengujian

\subsubsection{Pengujian Karakteristik Bioplastik}

Pengujian yang dilakukan pada penelitian bioplastik dari tepung jagung menggunakan penguat logam $\mathrm{ZnO}$ meliputi karakteristik tensile strength, elongasi, modulus young ${ }^{5}$, karakteristik kadar air, karakterisitik water vapour transmission rate $^{6}$, karakteristik ketebalan ${ }^{7}$, dan karakteristik biodegradasi ${ }^{8}$.

a. Tensile strength, \%Elongasi dan Modulus Young

Untuk mengetahui tensile strength, \% elongasi dan modulus young bioplastik dengan menggunakan alat Gotech Al-7000M. Dengan mengikuti prosedur kerja alat maka akan mendapatkan data tensile strength, \% elongasi dan modulus young bioplastik. Dari alat akan didapatkan data untuk gaya (force) yang diperlukan untuk memutuskan bioplastik dan perpanjangan bioplastik sampai bioplastik tersebut putus. Berikut ini adalah rumus menghitung tensile strength, elongasi dan modulus young bioplastik:

$$
\varepsilon=\frac{\Delta l}{l o} \times 100 \%
$$

Keterangan:

$$
\begin{array}{ll}
\varepsilon & =\text { elongasi }(\%) \\
l o & =\text { panjang mula-mula yang diukur }(\mathrm{cm}) \\
\Delta & =\text { pertambahan panjang }(\mathrm{cm}) \\
\sigma & =\frac{\text { Fmaks }}{A o}
\end{array}
$$

Keterangan:

$$
\begin{aligned}
& \sigma \quad=\text { tensile strength }\left(\mathrm{kgf} / \mathrm{cm}^{2}\right) \\
& \text { Fmaks }=\text { beban maksium }(\mathrm{kgf}) \\
& A o \quad=\text { luas penampang awal } \\
& M O E=\frac{T S(M p a)}{E B} \\
& \text { Keterangan: } \\
& \text { TS= tensile strength }(\mathrm{Mpa}) \\
& \mathrm{EB}=\text { elongasi }
\end{aligned}
$$

b. Kadar Air

Sampel yang di potong kecil kecil ditimbang sebanyak 1 gram dalam cawan porselen yang telah diketahui beratnya. Sampel dikeringkan dalam oven suhu $105^{\circ} \mathrm{C}$ selama 3 jam. Selanjutnya sampel didinginkan dalam desikator dan ditimbang. Prosedur diulangi sampai tercapai berat sampel yang konstan (selisih antara penimbangan kurang dari 0,2 mg). Perhitungan kadar air berdasarkan berat basah sebagai beikut:

Kadar Air $=\frac{B 0-B a}{B 0} \times 100 \%$

c. Water Vapour Transmission Rate

Bioplastik film yang akan diuji dipotong, kemudian wadah 1 diisi $15 \mathrm{~mL}$ aquades dan ditempat wadah 2 yang berisi silica gel. Sebelum itu, silica gel dikeringkan pada suhu $180^{\circ} \mathrm{C}$ selama 3 jam. Lalu wadah 2 disimpan pada suhu $25^{\circ} \mathrm{C}$. Pengukuran dilakukan pada jam ke 24 jam. Water vapour transmission rate dihitung dengan rumus: 


\section{WVTR $=\frac{\Delta W}{A \times t}$}

Keterangan:

$\mathrm{W}=$ perubahan berat bioplastik setelah 24 jam

$\mathrm{t}=$ waktu (24jam)

A $=$ luas area permukaan film $\left(\mathrm{m}^{2}\right)$

d. Ketebalan

Sampel diukur dengan menggunakan mikrometer pada 5 tempat yang berbeda kemudian hasil pengukuran dirata-rata sebagai hasil ketebalan film. Ketebalan dinyatakan dalam $\mathrm{mm}$ sedangkan mikrometer yang digunakan memiliki ketelitian $0,01 \mathrm{~mm}$.

e. Biodergadasi

$$
\begin{aligned}
& \% \text { Kehilangan berat } 1=\frac{w 1-w 2}{w 1} \times 100 \% \\
& \text { Perkiraan waktu degradasi } 1=\frac{100 \%}{\% \text { kehilangan berat }} \times \text { waktu uji }
\end{aligned}
$$

\section{Hasil dan Diskusi}

3.1. Analisis hasil karakterisasi

\subsubsection{Karakteristik Tensile Strength}

Pengukuran tensile strength berguna untuk mengetahui besarnya gaya yang dicapai untuk mencapai tarikan maksimum pada setiap satuan luas area film untuk merenggang atau memanjang ${ }^{7}$. Dari hasil statistik yang didapati, hasil analisa kekuatan tensile strength bioplastik dari tepung jagung dengan penguat logam $\mathrm{ZnO}$ yang tertinggi terjadi pada sampel variasi massa 7 gram yaitu 4,018 Mpa dan pada sampel variasi massa 10 gram yaitu 2,744 Mpa. Dapat dilihat pada gambar 1.

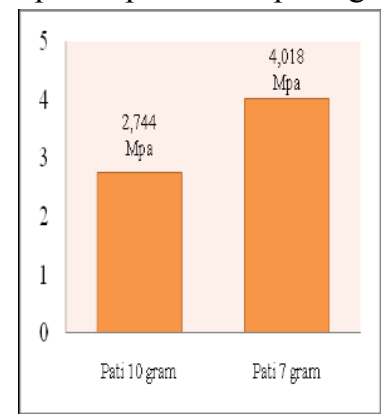

Gambar 1. Grafik Karakteristik Tensile Strength

Pada gambar 1 terlihat bahwa semakin tinggi massa pati jagung akan menurunkan tensile strength dari bioplastik. Hal ini diduga seiring dengan adanya peningkatan gliserol akan menghasilkan pengurangan interaksi intermolekuler dan peningkatan pergerakan dari rantai polimer, sehingga kuat tarik akan menurun ${ }^{5}$.
Hubungan sifat mekanik ini berhubungan dengan interaksi $\mathrm{ZnO}$ dengan pati. Selama proses interkalasi, partikel penguat logam $\mathrm{ZnO}$ akan masuk dan berikatan dengan lapisan permukaan matriks polimer. $\mathrm{ZnO}$ berperan sebagai agen yang dapat meningkatkan nilai tensile strength dari bioplastik tetapi menurunkan elongasi karena turunnya mekanisme plastisasi dari matriks pati jagung. $^{2}$

Meningkatnya nilai tensile strength pada film bioplastik karena logam $\mathrm{Zn}^{2+}$ sebagai filler yang menjadikan penghubung dan penggantian ikatan hidrogen interamolekul dan intermolekul yang hilang saat sudah ditambahkan pati dan gliserol. ${ }^{9}$

Berdasarkan penelitian yang dilakukan Yuana Elly bioplastik menggunakan pati kulit pisang kepok nilai tensile strength berkisar 0,601 Mpa. ${ }^{9}$ Dan yang dilakukan Fauzi Akbar bioplastik menggunakan pati kulit singkong nilai tensile strength yang didapati $0,2122 \mathrm{kgf} / \mathrm{mm}^{2} .{ }^{19}$ Dalam penelitian ini nilai kuat tarik yang didapati belum mencapai standar internasional ASTM-D638 (at 50 $\mathrm{mm} / \mathrm{min}$ ).

\subsubsection{Karakteristik Elongasi}

Dari hasil statistik yang didapati, hasil analisa elongasi (perpanjangan) bioplastik dari tepung jagung dengan penguat logam $\mathrm{ZnO}$ menunjukkan hasil yang sebaliknya. Pada sampel variasi massa 7 gram yaitu $28,46 \%$ dan sampel variasi massa 10 gram yaitu 32,383\%. Dapat dilihat pada gambar 2 .

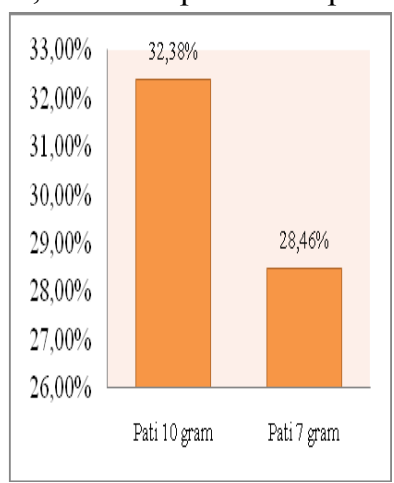

Gambar 2. Grafik Karakteristik Elongasi

Berdasarkan hasil penelitian penurunan nilai elongasi disebabkan seiring meningkatnya jumlah massa pati. Peningkatan nilai elongasi ini bisa juga dikarenakan sifat asli gliserol sebagai plasticizer. Bahwa semakin banyak gliserol maka persentasi elongasi nya juga semakin elastis. Selain itu, penambahan bahan plasticizer sangat penting untuk mengatasi film yang rapuh dan meningkatkan fleksibilitas. $^{5}$ 
Bisa dilihat dari gambar 2 telah terjadinya peningkatan nilai elongasi. Hal ini adanya pengaruh penambahan $\mathrm{ZnO}$ terhadap sifat mekanik bioplastik menunjukkan sifat berkebalikan antara tensile strength dan elongasi. ${ }^{2} \quad$ Penguat yang semakin meningkat mengakibatkan tensile strength semakin meningkat. Sebaliknya, massa penguat tinggi akan mengakibatkan elongasi menurun. ${ }^{2}$

Berdasarkan penelitian yang dilakukan oleh Siswanti dengan menggunakan komposit glukomanan umbi iles-iles dan maizena didapati nilai elongasi berkisar $15,56-30,50 \%{ }^{10}$ Dan Ahmad Syarifuddin menggunakan pektin dari jeruk bali dan pati garut didapati nilai elongasi berkisar 22,67-53,11\%. ${ }^{11}$ Dalam penelitian ini nilai elongasi dari bioplastik telah memenuhi golongan tersebut, yaitu Standar Plastik Internasional (ASTM 5336) yang mengatakan besarnya persentase elongasi untuk plastik Poly Lactid Acid (PLA) dari jepang mencapai 9\%. ${ }^{12}$ Namun belum memenuhi golongan standar JIS 1975.

\subsubsection{Karakteristik Modulus Young}

Dari hasil statistik yang didapati, hasil analisa Modulus Young bioplastik dari tepung jagung dengan penguat logam $\mathrm{ZnO}$ yang tertinggi terjadi terjadi pada sampel variasi massa 7 gram yaitu 14,08617709 Mpa berbeda sekali yang terjadi pada sampel variasi massa 10 gram yaitu 8,9031026535 Mpa.

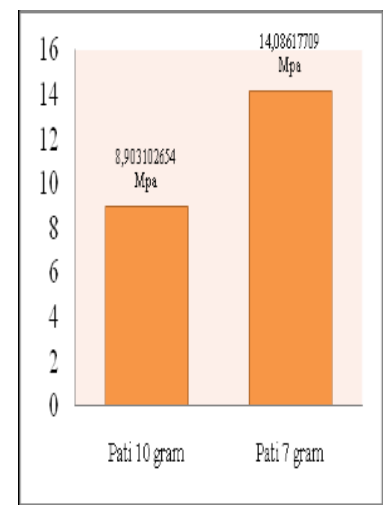

Gambar 3. Grafik Karakteristik Modulus Young

Karena modulus young dipengaruhi oleh elongasi dan tensile strength, maka semakin besar nilai elongasi dan tensile strength maka modulus young akan semakin besar dan benda semakin elastis. Jenis pati tidak berpengaruh nyata terhadap modulus young, namun variasi massa pati berpengaruh nyata. ${ }^{13}$

3.1.4 Karakteristik Kadar Air
Kadar air merupakan parameter penting untuk menentukan efek plasticizing air pada film biopolimer. $^{5}$

\section{Tabel 1.Hasil Kadar Air}

\begin{tabular}{l|c}
\hline \multicolumn{1}{c|}{ Sampel } & Kadar Air (\%) \\
\hline Tepung jagung 10 gram & 13,5 \\
\hline Tepung jagung 7 gram & 14,5 \\
\hline
\end{tabular}

Berdasarkan gambar 4 bioplastik berkisar antara 13,5-14,5 \%. Kadar air dengan perlakuan penambahan massa pati jagung tidak menyebabkan perubahan yang signifikan terhadap kadar air bioplastik. Hal ini di tandai dengan berkurangnya berat bioplastik yang cenderung menunjukkan hasil yang sama. Karena adanya peningkatan sifat hidrofilik dari bioplastik dengan semakin bertambahnya gugus $\mathrm{OH}$ dari gliserol sehingga akan semakin meningkat jumlah air yang di ikat. ${ }^{5}$

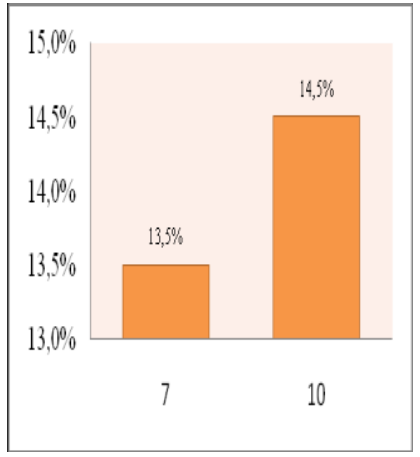

\section{Gambar 4. Grafik Karakteristik Kadar Air}

Gliserol termasuk humektan karena memiliki gugus hidroksil yang dapat membentuk ikatan hidrogen dalam air. Jika kelembaban relatif bioplastik berbasis pati berada dibawah 20-25\%, maka film dapat mengalami pecah. ${ }^{5}$ Sedangkan, $\mathrm{ZnO}$ yang bersifat hidrofobik selain sebagai penguat juga berfungsi sebagai filler sehingga dapat menutupi rongga atau pori yang terdapat di permukaan film bioplastik. Hal ini membuat film bioplastik mengalami penurunan daya serap air. ${ }^{9}$

Respon kadar air yang dikehendaki dibawah 20\% sesuai dengan persyaratan SNI (Standai Internasional Indonesia), dalam penelitian ini respon kadan air dipilih 13,5-14,5\%, dengan rentang tersebut dihasilkan film bioplastik yang tidak terlalu kering sehingga tidak rapuh dan tidak lembab. Selain itu kadar air yang tinggi rentan terhadap pertumbuhan mikroba. ${ }^{17}$

Berdasarkan penelitian yang dilakukan sebelumnya oleh Wini Setiani menggunakan pati 
sukun dan kitosan didapati respon kadar air 22,38\%. ${ }^{19}$ Dan Moch Futuhul Arifin menggunakan pati jagung, HPMC, dan sorbitol didapati respon kadar air $15,46-15,84 \%,{ }^{18}$ sehingga dalam ini dapat disimpulkan penelitian tepung jagung dengan menggunakan penguat logam $\mathrm{ZnO}$ lebih kecil respon kadar air yang didapat dan telah memenuhi SNI.

3.1.5 Karakteristik Water Vapour Transmission Rate

Permeabilitias uap air merupakan jumlah uap air yang hilang per satuan waktu dibagi luas area film. ${ }^{7}$ Uji WVTR adalah salah satu uji yang menyatakan jumlah uap air yang dapat terlewati melalui lapisan film bioplastik. ${ }^{9}$

Tabel 2. Hasil Water Vapour Transmission Rate (WVTR)

\begin{tabular}{l|c}
\hline \multicolumn{1}{c|}{ Sampel } & $\begin{array}{c}\text { Transmisi Uap } \\
\text { Air(g/m }\end{array}$ \\
& \\
\hline Tepung jagung 10 gram & 1,51515 \\
\hline Tepung jagung 7 gram & 0,4329 \\
\hline
\end{tabular}

Berdasarkan Gambar 5 dapat dilihat bahwa migrasi uap air umumnya terjadi pada bagian film yang hidrofilik. Semakin besar nilai hirofobisitas film, maka nilai laju transmisi uap air film tersebut akan semakin turun, jadi dapat disimpulkan semakin besar hidrofilisitas film, maka nilai laju transmisi uap air akan semakin naik. ${ }^{7}$

WVTR bioplastik mengalami peningkatan dengan penambahan massa pati yang digunakan. Hal ini di duga karena oleh sifat plasticizer yang bersifat hidrofilik dan mampu menurunkan tegangan antar molekul pada matriks film yang menyebabkan ruang antar molekul semakin besar sehingga uap air bisa menembus film. ${ }^{5}$

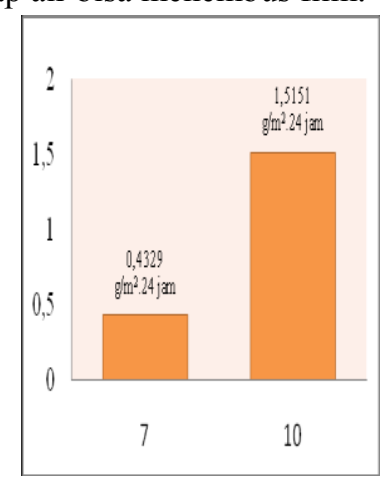

Gambar 5. Grafik Karakteristik WVTR

Pada variasi massa pati 10 gram didapati nilai WVTR sebesar 1,51515 g/m2.jam dan pati 7 gram didapati nilai WVTR sebesar 0,4329 g/m2.jam, nilai WVTR akan semakin besar seiring bertambahnya massa pati, seperti yang ditunjukkan pada Gambar 5. Hal tersebut dapat disebabkan karena semakin banyaknya jumlah pati maka akan semakin banyak pula pori di permukaan film bioplastik, sehingga semakin banyak uap air yang dapat terlewat.

Semakin banyak gliserol maka semakin banyak air yang dapat terikat pada bioplastik. Hal ini dapat menyebabkan uap air tidak dapat melewati bioplastik dan terserap oleh desikan penambahan $\mathrm{ZnO}$ juga menyebabkan penurunan nilai WVTR pada bioplastik. Hal ini dikarenakan sifat $\mathrm{ZnO}$ yang hidrofobik, sehingga uap air dapat lewat akan semakin rendah. ${ }^{9}$ Penurunan nilai WVTR terjadi karena $\mathrm{ZnO}$ mempunyai resistansi yang lebih baik terhadap air jika dibandingkan dengan matriks pati. Penambahan $\mathrm{ZnO}$ memberikan penghalang bagi molekul air untuk lewat. ${ }^{2}$ Semakin kecil migrasi uap air yang terjadi pada produk yang dikemas oleh film, maka semakin bagus sifat film dalam menjaga umur simpan produk yang dikemas. ${ }^{7}$

Berdasarkan penelitian sebelumnya yang dilakukan oleh Sri Wahyu Murni laju WVTR 3,098 g/m2.24 jam. ${ }^{1}$ Penelitian yang dilakukan oleh Eldo Marbun nilai laju WVTR 10,097 g/m².24 jam, ${ }^{2}$ bioplastik dari tepung jagung menggunakan penguat logam $\mathrm{ZnO}$ masih memiliki rata-rata transmisi uap air yang lebih kecil. Berdasarkan hasil transmisi uap air yang didapati dalam penelitian ini telah memenuhi standar JIS $1975 .{ }^{14}$

\subsubsection{Karakteristik Ketebalan}

Ketebalan merupakan sifat fisik yang akan mempengaruhi laju transmisi uap air, gas dan senyawa volatil serta sifat lainnya (tensile strength dan elongasi). ${ }^{7}$

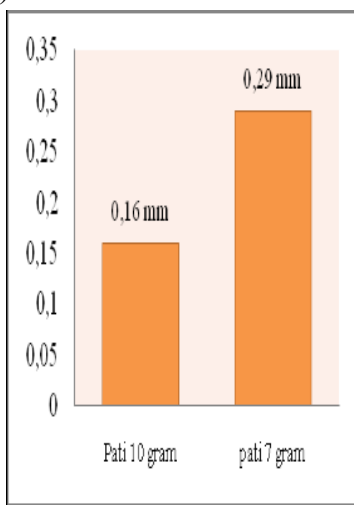

Gambar 6. Grafik Karakteristik Ketebalan 
Pengaruh perubahan massa pati jagung terhadap ketebalan bioplastik ditujukkan pada gambar 6 bahwa pada gambar menunjukkan massa pati jagung berpengaruh terdapat ketebalan bioplastik. Semakin tinggi massa pati jagung menyebabkan ketebalan bioplastik akan semakin meningkat. Semakin banyak massa pati jagung yang digunakan akan menyebabkan struktur polimer penyusun film menjadi lebih banyak sehingga menghasilkan film yang semakin tebal. ${ }^{6}$

Plasticizer yang ditambahkan dapat berikatan dengan pati membentuk polimer pati-plasticizer. Ikatan antara pati dengan pati digantikan dengan ikatan antara pati-gliserol-pati sehingga ketebalan meningkat seiring dengan bertambahnya gliserol dalam film. ${ }^{5}$

Berdasarkan hasil penelitian ini nilai ketebalan berkisar 0,16-0,29 $\mathrm{mm}$ telah memenuhi standar yang dipersyaratkan oleh JIS 1975, Yaitu maksimal $0,25 \mathrm{~mm} .{ }^{14}$ Hasil penelitian ini tidak jauh berbeda dengan penelitian yang dilakukan oleh Agoes dengan nilai ketebalan 0,13-0,20 $\mathrm{mm}$ bahwa ketebalan fim dipengaruhi oleh luas cetakan, volume larutan, dan banyaknya total padatan dalam larutan. ${ }^{15}$ Pada penelitian Anggraeni Dwi Pangesti mendapatkan nilai ketebalan $0,18 \mathrm{~mm}$ yang mengatakan bahwa ketebalan akan meningkat seiring dengan bertambahnya konsentrasi asam palmitat. ${ }^{16}$

\subsubsection{Karakteristik Biodegradasi}

Pengujian biodegradasi bertujuan untuk mengetahui laju degradasi bioplastik sehingga diperkirakan berapa lama waktu yang dibutuhkan bioplastik hingga terurai. Kemudian, bioplastik dikubur dalam tanah ditimbang tiap satuan waktu.

Pada pengujian ini menunjukkan beberapa kelemahan. Sampel bioplastik yang berupa film sulit dikontrol saat pengujian. Berkurangnya fraksi massa bioplastik tidak dapat ditentukan penyebabnya secara menyeluruh apakah disebabkan oleh mikroorganisme atau degradasi absorbsi air yang masuk kedalam bioplastik.

Tanah yang digunakan adalah tanah yang bersumber dari tempat sampah. Sampel massa di buat ukuran $3 \mathrm{~cm} \times 3 \mathrm{~cm}$. Setiap sampel di timbang untuk mengetahui berat awalnya. Pada variasi massa 7 gram didapati berat awal yaitu 0,215 gram dan variasi massa 10 gram didapati berat awal yaitu 0,395 gram. Pengujian ini dilakukan sampai 28 hari lamanya. Pada hari ke 28 bioplastik di timbang kembali untuk mengetahui berat akhir. Pada variasi massa 7 gram didapati berat akhir yaitu 0,2 gram dan variasi massa 10 gram didapati berat akhir yaitu 0,38 gram. Dari hasil pengukuran ini diketahui bahwa adanya penurunan berat setiap massa.

Tabel 3.Hasil Biodegradasi

\begin{tabular}{l|c|c}
\hline \multicolumn{1}{c|}{ Sampel } & $\begin{array}{c}\text { \%Kehilangan } \\
\text { Berat }\end{array}$ & $\begin{array}{c}\text { Perkiraan } \\
\text { Waktu } \\
\text { Degradasi } \\
\text { (hari) }\end{array}$ \\
\hline $\begin{array}{l}\text { Tepung jagung 10 } \\
\text { gram }\end{array}$ & $3,7798 \%$ & 455,0035 \\
\hline $\begin{array}{l}\text { Tepung jagung 7 } \\
\text { gram }\end{array}$ & $7,0346 \%$ & 809,07935 \\
\hline
\end{tabular}

Dari hasil statistik yang dilakukan maka didapati \%kehilangan berat setiap variasi massa bioplastik. Hasil tertinggi terjadi pada bioplastik dengan variasi massa 7 gram yaitu 7,0346\% dan variasi massa 10 gram yaitu 3,7798\%. Dari hasil pengujian diperoleh bahwa bioplastik dari tepung jagung menggunakan penguat logam $\mathrm{ZnO}$ terdegradasi pada hari ke-28.

Efek pati jagung dan $\mathrm{ZnO}$ terhadap peningkatan ketebalan film, karena bahan itu maka waktu hancurnya menjadi lama. Film tidak segera hancur akibat ketebalannya, maka dalam hal ini waktu hancur merupakan fungsi dari ketebalan. Dan peningkatan jumlah gliserol akan meningkatkan kekuatan film. ${ }^{17}$

Biodegrabilitas yang lebih rendah karena partikel $\mathrm{ZnO}$ bertindak sebagai penghalang laju difusi air kedalam polimer. Partikel $\mathrm{ZnO}$ bertindak sebagai agen penyerang mikroorganisme sehingga kadar ZnO yang cukup besar, frekuensi penyerang mikroorganisme pengurai menjadi tinggi. Oleh karena itu biodegrabilitas bioplastik dengan penguat $\mathrm{ZnO}$ mempunyai kecenderungan lebih lambat. ${ }^{4}$

Pengujian ini erat kaitannya antara kegiatan beberapa mikroba. Hal ini dijumpai bercak-bercak kecil pada bioplastik dan perubahan warna yang terjadi. Hal ini mungkin disebabkan karena jumlah nutrisi dalam tanah bakaran lebih banyak dibandingkan tanah lainnya sehingga jumlah dan jenis mikrobanya juga lebih banyak. Mikroba yang membantu proses degradasi dalam tanah adalah pseudomous dan bacillus yang memutus rantai polimer menjadi monomer-monomernya. Oleh karena itu, terjadi kinerja yang sinergis antara kegiatan beberapa mikroba. ${ }^{8}$

Degradasi polimer dapat disebabkan oleh beberapa faktor, seperti sinar matahari, panas, umur 
dan faktor alam. Dari sisi ketebalan film plastik dapat diketahui, tebalnya bioplastik tidak berpengaruh terhadap cepat atau lambatnya terbiodegradasi. Faktor utama yang paling menentukan cepat atau lambatnya film plastik terdegradasi adalah penyusun utama dari film plastik itu sendiri. Dari hasil inilah, bioplastik dari tepung jagung menggunakan penguat logam $\mathrm{ZnO}$ dapat dikatakan sebagai plastik yang ramah lingkungan.

\section{Kesimpulan}

Berdasarkan hasil penelitian, maka dapat disimpulkan bahwa tepung jagung dapat digunakan sebagai bahan pembuatan bioplastik menggunakan penguat logam $\mathrm{ZnO}$. Hasil analisa pengujian dengan menjadikan $\mathrm{ZnO}$ sebagai bahan tambahan dalam pembuatan bioplastik menunjukkan hasil terbaik hal ini dibuktikan dengan nilai pengujian yaitu karakteristik Tensile strength (Mpa), Elongasi (\%), dan Modulus Young secara berturut-turut pada pati 7 gram adalah 4,018 Mpa, 28,46\%, dan 14.08617709 Mpa, pada pati 10 gram adalah 2,744 Mpa, 32,383\%, dan 8.9031026535 Mpa. Yang telah mencapai standar JIS. Karakteristik ketebalan pada pati 7 gram adalah $0,16 \mathrm{~mm}$ dan pada pati 10 gram adalah 0,29 mm. Karakteristik Water Vapour Transmission Rate pada pati 7 gram adalah 0,4329 $\mathrm{g} / \mathrm{m} 2.24$ jam dan pada pati 10 gram adalah $1,52525 \mathrm{~g} / \mathrm{m}^{2} .24$ jam. Karakteristik kadar air pada pati 7 gram adalah $14,5 \%$ dan pada pati 10 gram adalah 13,5\%. Karakteristik biodegradasi \% kehilangan berat pada pati 7 gram adalah 7,0346\% dan perkiraan waktu degradasi 809,07935 hari. Dan pada pati 10 gram adalah $3,7798 \%$ dan perkiraan waktu degradasi 455,0035 hari.

\section{Referensi}

1. Sri Wahyu Murni, Harso Pawignyo, Desi Widyawati, dan Novita Sari. (2013, 3)."Pembuatan Edible Film dari Tepung Jagung (Zea Mays L.) dan Kitosan." Jurnal Pengembangan Teknologi Kimia untuk Pengolahan Sumber Daya Alam Indonesia. ISSN 1693-4393.

2. Eldo Sulatro Marbun. "Sintesis Bioplastik dari Pati Ubi Jalar menggunakan Penguat Logam ZnO dan Penguat Selulosa." Skripsi, Fakultas Teknik Universitas Indonesia, Indonesia, 2012.
3. Bayandori, M.A., Badraghi, T.N \& Kazemzad,M. (2009, 4). "Synthesis of $\mathrm{ZnO}$ Nanoparticles And Electrodeposition of Polypyrole/ZnO Nanocomposite Film." Int $J$ Electrochem Sci, 4,247-257.

4. Wang Z. (2007). "Nanopiezotronies Advanced Materials.” 19.p:889-892

5. Daman Huri. (2014, 10). "Pengaruh Konsentrasi Gliserol dan Ekstrak Ampas Kulit Apel terhadap Karakteristik Fisik dan Kimia Edible Film”. Jurnal Pangandan Agro industri Malang. Vol. 2 No 4 p.29-40.

6. Riza Rizki Amaliyah. $(2014,7)$.” Karakterisasi Edible Film dari Pati Jagung dengan Penambahan Filtrat Kunyit Putih sebagai Antibakteri." Jurnal Pangan dan Agroindustri Vol.2 No.3 p.43-53.

7. Agung Adi Nugroho. (2013, 1). "Kajian Pembuatan Edible Film Tapioka dengan Pengaruh Penambahan Pektin Beberapa Jenis Kulit Pisang terhadap Karakteristik Fisik dan Mekanik." Jurnal Jurusan Teknologi Hasil Pertanian Universitas Sebelas Maret Surakarta. Vol 2 No. 1.

8. Tuty Dwi Sriaty. (2013, 11). "Pembuatan Plastik Kemasan Terbiodegradasikan dari Polipropylena Tergrafting Maleat Anhidrida dengan Bahan Pengisi Pati Sagu Kelapa Sawit.” Program Studi FMIPA Universitas Sumatera Utara. Vol. 3 No.2 p. 110-116.

9. Yuana Elly Agustin. (2016,4). "Sintesis Bioplastik dari Kitosan-Pati Kulit Pisang Kepok dengan Penambahan Zat Aditif." Jurnal Jurusan Teknik Kimia Fakultas Teknik Universitas Surabaya Raya Kalirungkut Jawa Timur. Vol. 10, No.2. p.2-16.

10. Siswanti. "Karakterisasi Edible Film Komposit dari Glukomanan Umbi Iles-Iles (Amorphopallus muelleri Blume) dan Maizena." Skripsi. Fakultas Pertanian Universitas Sebelas Maret Surakarta. 2008. p:52.

11. Ahmad Syarifuddin. (2015, 9). "Karakterisasi Edible Film dari Pektin Albedo Jeruk Bali dan Pati Garut." Jurnal Pangan dan Agroindustri Vol. 3 No 4 p.1538-1547.

12. I Gusti Agung. (2016, 3). "Pengaruh Campuran Bahan Komposit dan Konsentrasi Gliserol terhadap Karakteristik Bioplastik dari Pati Kulit Singkong dan Kitosan.” Jurnal Teknologi Industri Pertanian Fakultas Teknologi Pertanian Unud.

13. Melanie Cornelia. (2013, 4). "Pemanfaatan Pati Biji Durian (Durio zibethinus murr.) dan pati Sagu (Metroxylon sp.) dalam Pembuatan Bioplastik." Jurnal Kimia Kemasan Bogor, Vol.35 No.1p. 20-29. 
14. Budi Santoso. (2013,7). "Karakteristik Film Pelapis Pangan dari Serumi Belut Sawah dan Tapioka." Jurnal Teknologi dan Industri Pangan Sumatera Selatan. Vol. 24 No.1. p. 4853.

15. Agoes M Jacoeb. (2014,4). "Edible Film From Lindur Fruit Starch With Addition Of Glycerol andCarrageenan."Jurnal Departemen Teknologi Hasil Perairan, Fakultas Perikanan dan Ilmu Kelautan, Institut Pertanian Bogor. Vol. 17 No. 1.

16. Anggraeni Dwi Pangesti.(2014, 6)." Karakteristik Fisik, Mekanik dan Sensoris Edible Film dari Pati Talas pada Berbagai Konsentrasi Asam Palmitat." e-J. Agrotekbis 2 (6) : 604-610

17. Moch. Futuchul Arifin. (2009,12). "Formulasi Edible Film Ekstrak Daun Sirih (Piper betle L.)sebagai Antihalitosis." Jurnal Kongres Ilmiah ISFI XVII Jakarta.

18. Wini Setiani. (2013,11). "Preparasi dan Karakterisasi Edible Film dari Poliblend Pati Sukun-Kitosan."Jurnal Jurusan Kimia Fakultas Sains dan Teknologi UIN Sunan Gunung Djati Bandung. Vol. 3 No. 2. P.100-109.

19. Fauzi Akbar. (2013). "Pengaruh Waktu Simpan Film Plastik Biodegradasi dari Pati Kulit Singkong terhadap Sifat Mekanikalnya.” Jurnal Jurusan Teknik Kimia USU. Vol.2 No.2 p.11-15. 